慶應義塾大学学術情報リポジトリ

Keio Associated Repository of Academic resouces

\begin{tabular}{|c|l|}
\hline Title & The effect of temperature on fluorescence for liquid scintillators and their solvents \\
\hline Sub Title & \\
\hline Author & $\begin{array}{l}\text { 本間, 義夫(Honma, Yoshio) } \\
\text { 村瀬, 裕子(Murase, Yuko) } \\
\text { 曽根原, 一江(Sonehara, Kazue) }\end{array}$ \\
\hline Publisher & 共立薬科大学 \\
\hline Publication year & 1986 \\
\hline Jtitle & $\begin{array}{l}\text { 共立薬科大学研究年報 (The annual report of the Kyoritsu College of } \\
\text { Pharmacy). No.31 (1986.) ,p.66-67 }\end{array}$ \\
\hline JaLC DOI & \\
\hline Abstract & \\
\hline Notes & 抄録 \\
\hline Genre & Technical Report \\
\hline URL & https://koara.lib.keio.ac.jp/xoonips/modules/xoonips/detail.php?koara_id=AN00062898-0000003 \\
\hline
\end{tabular}

慶應義塾大学学術情報リポジトリ(KOARA)に掲載されているコンテンツの著作権は、それぞれの著作者、学会または出版社/発行者に帰属し、その権利は著作権法によって 保護されています。引用にあたっては、著作権法を遵守してご利用ください。

The copyrights of content available on the KeiO Associated Repository of Academic resources (KOARA) belong to the respective authors, academic societies, or publishers/issuers, and these rights are protected by the Japanese Copyright Act. When quoting the content, please follow the Japanese copyright act. 


\title{
The Effect of Temperature on Fluorescence for Liquid Scintillators and Their Solvents*
}

\author{
Yoshio Homma, Yuko Murase and Kazue Sonehara \\ 本間義夫，村瀬裕子，曾根原一江
}

Since Selieger (1956) reported that the light output of gas-free liquid scintillator increases with decreasing temperature, the temperature effect of fluorescence spectra in liquid scintillator has been long the subject of discussion and much contradictory results have been presented. Laustriat (1960) explained the temperature effect in terms of the temperature response of photomultiplier tubes. Earlier reports on the temperature dependence of the fluorescence emission from concentrated PPO (2,5-diphenyloxazole)solution in xylene (Berlman 1961) and toluene (Horrocks 1970) described a decrease in fluorescence with a decrease in temperature. Kaczmarczyk (1969) showed that the counting efficiency of ${ }^{14} \mathrm{C}$ and ${ }^{3} \mathrm{H}$ is improved on sample-cooling and concluded that the effect is contributed to the shift of the balance-point and calibration curve for external standardization, etc.

In the course of the spectral studies described in the preceding papers (Homma 1985, 1985), however, we have observed the pulse-height distribution for alpha- and betaparticles and internal conversion electrons in a dilute PPO solution $(4 \mathrm{~g} / 1)$ increases markedly with decreasing temperature and suggested that the temperature effect may be attributed to the increase of excimer fluorescence of the solvent, toluene. Since the same temperature effect appears to be general in other liquid scintillators of some other aromatic hydrocarbons, a further investigation was undertaken to measure the fluorescence spectra from several aromatic hydrocarbons such as benzene, $o$-xylene, $m$-xylene, ethylbenzene and cumene (isopropylbenzene), and dilute PPO solutions in these hydrocarbons under alpha particle and internal conversion electron excitation at lower temperatures.

The differential pulse-height distributions for ${ }^{241} \mathrm{Am}$ and ${ }^{131 \mathrm{~m}} \mathrm{Xe}$ in PPO solutions of benzene, $o$-xylene, $m$-xylene, ethylbenzene, and cumene measured with the liquid scintillation system at temperatures from -54.7 to $24.7^{\circ} \mathrm{C}$ are presented. Cooling the scintillator solution markedly affects the pulse-height distributions for these samples: The alpha peak of ${ }^{241} \mathrm{Am}$ ( 5.49 and $5.44 \mathrm{Mev}$ ) and the peak of internal conversion electrons of ${ }^{131 \mathrm{~m} X \mathrm{Xe}}$ (134 and $164 \mathrm{keV}$ ) shift from the initial pulse-height position, i.e., the ordinary temperature positions, toward higher pulse-height with decreasing temperature. These pulse-height shift observed do not cause an increase in counting rate because alpha-particles and energetic internal conversion electrons are counted with almost $100 \%$ counting efficiency

* 本報告は Int. J. Appl. Radiat. Isotopes,（1986）飞発表（in press) 
at ordinary temperature (Horrocks 1964), whereas, as has been described in the preceding papers (Homma 1985, 1985), cooling liquid scintillation samples of beta-emitters increases the counting rates, because even the very soft beta-particles from beta-emitters come to be counted.

Pure benzene, o-xylene, $m$-xylene, ethylbenzene and cumene were measured at a few different temperatures under UV excitation and the relative fluorescence intensity was plotted against wavelength. Cooling the pure compound dramatically affects the emission spectrum: The peak of the fluorescence spectra shifts from the ordinary temperature position, toward longer wavelength with decreasing temperature.

In addition to the red shift, changes in fluorescence intensity also occur when the temperature of the pure compound is changed. The relative intensity from the compound, which is plotted, increases markedly with decreasing temperature.

In conclusion, our observations have been that in each aromatic hydrocarbons tested the increase in fluorescence intensity at lower temperatures is accompanied by the formation of excimer and that the increase in energy transfer between solvent molecules, and hence, in light output of liquid scintillator occurs, because the condition of excimer formation is the parallel orientation of two adjacent molecules. Since there are the compounds which have been observed not to show excimer fluorescence under the experimental conditions, experiments are being undertaken to further study the problem by observing other pure aromatic liquids as well as the solution of them in greater depth. 